\title{
The Amish and COVID-19: A Media Survey
}

\author{
Erik Wesner \\ Founder \& Editor, Amish America (amishamerica.com) \\ ewesner@gmail.com
}

\begin{abstract}
The Amish are a frequent topic of media coverage. The simple fact of Amish involvement often elevates a mundane story to a newsworthy one. Accordingly, the Amish received extensive coverage with regard to the COVID-19 pandemic. In this paper, I survey media output on the Amish and COVID-19 for the period of March to November 2020, drawing on conventional media stories covered on the Amish America website in addition to many others. I identify and analyze several common themes of Amish COVID coverage, including Amish attitudes toward the pandemic, negative reporting, and Amish responses to both the virus and the restrictions put in place to combat the pandemic.
\end{abstract}

Submitted December 7, 2020; accepted January 8, 2021; published March 24, 2021

https://doi.org/10.18061/jpac.v1i2.8022

Keywords: COVID-19, media, health care, tourism, Amish schools, Amish churches

$\mathrm{T}$

he novel coronavirus and associated COVID-19 pandemic created great disruption throughout the world from public health, economic, social, diplomatic, and other perspectives. As local, regional, and national governments implemented various measures restricting social interaction, business, and other forms of public intercourse, communities around the United States responded in various ways, ranging from full compliance to reluctant and selective adherence to some rules and guidelines to outright thwarting of government decrees. A related consideration is the fact that the virus had varying health impacts on communities and regions throughout the countrytypically with urban areas being hardest hit first, and the more rural states and regions initially registering lower numbers of cases and associated deaths. As time has passed, however, urbanrural differences have mostly disappeared as COVID-19 ebbs and flows throughout various regions of North America.

One rural community that found itself again in the spotlight, this time in the context of public response to a major viral outbreak, was the Old Order Amish. How did the Amish respond to the COVID-19 pandemic and the requirements put in place by authorities? How were they informed about this public health threat? Did Amish comply with COVID-related restrictions? How did Amish respond to help fulfill public health needs during this time? A wide assortment of media stories, beginning in March 2020, addressed these and related topics.

This survey of media coverage of Amish stories related to the pandemic will examine these and other questions, taking into account the Amish actions during this time, and the tone and tenor of media coverage of the Amish in the COVID context, drawing from approximately 90 conventional media sources published over the period of March through November 2020. Many 
of these media accounts were the basis of a steady stream of stories found on the Amish America website (https://amishamerica.com).

Media coverage has been grouped into seven main themes: (1) non-Amish (a.k.a. "English," an Amish term for non-Amish people) outreach to the Amish concerning awareness and testing, (2) Amish responses to the virus, with a focus on the first month of the pandemic, (3) non-adherence by the Amish to COVID regulations, (4) Amish fulfilment of the need for masks and other PPE (personal protective equipment), (5) COVID-19 cases among the Amish, (6) the spring "reopening" and subsequent period, and (7) "collateral damage" - stories demonstrating unexpected negative side effects disproportionately affecting Amish communities.

This study of how the Amish were covered in traditional media for a largely non-Amish readership relies primarily on widely available, online "English" media sources, rather than the numerous, though less readily accessible, Amish publications such as scribe papers, topical periodicals, and church newsletters. All sources cited here were accessible in online format.

In the final section, I examine several themes that emerge in the coverage, including the contrast between Amish attitudes about the pandemic and those more common among the English, sources of negative coverage, and the ways Amish responded to the disruptions and challenges created by COVID-19.

\section{Theme \#1: English Outreach to the Amish}

Much of the earliest coverage of the Amish and COVID-19 centered around outreach and awareness efforts in Amish communities. We saw various examples of non-Amish engaging Amish populations with two primary aims: (1) awareness and education, and (2) clinical testing with the goal of identifying infected members of the Amish community and controlling the disease. The driving spirit behind these efforts was frequently reported to be concern for the well-being of this population by sympathetic outsiders, considering that news channels such as social media and other online sources relied upon by the general public are absent or less frequently seen by the Amish. There was also likely concern from some parties about an uninformed Amish population becoming infected and unwittingly spreading disease among the general public.

One of the first references, if not the first, to the Amish and coronavirus came as a small mention in a report in the Washington Times Herald regarding southern Indiana's Daviess County community, with a county public health nurse saying that the Amish were "very aware of the information out there" (Washington Times Herald, March 6, "Daviess County readies for potential Corona virus cases"). But the first significant media coverage focusing primarily on the Amish and COVID-19 came in the form of an article in Lancaster Online dated March 13 ("Health officials working to provide Plain sect members with COVID-19 information").

Further articles followed within this theme of reaching out to Amish communities for awareness and educational purposes. In the Swartzentruber settlement at Ethridge, Tennessee, health departments hosted "well-attended" meetings to share information on coronavirus with the local Amish community, the state's largest (newschannel5.com, March 19, "Health department 
works to alert Tennessee Amish community of COVID-19"). Other health department-driven efforts were reported in Kentucky and Wisconsin (Kentucky New Era, March 23, "Governor lauds Todd County's outreach to Amish, Mennonites"; wxow.com, August 10, "How Mennonite and Amish communities stay informed about COVID-19"). In Ashland County, Ohio, the sheriff's office delivered material on the coronavirus pandemic to Amish and Mennonite communities on behalf of the county health department (Columbus Dispatch, March 23, "Amish community is taking coronavirus seriously").

While many efforts were driven by official organizations, at least one was propelled by the initiative of private citizens. In Iowa, a concerned non-Amish resident distributed CDC information on COVID-19, placing material "in the mailboxes of as many Amish families as she could," and indirectly pushing action by county health departments in the Kalona community (Des Moines Register, March 24/25, "In eastern Iowa, concerned neighbors take steps to ensure Amish get word about COVID-19"). In St. Lawrence County, New York, a combination of endeavors including postcards sent by a state senator, flyers delivered to mailboxes by a village trustee, and a letter to the Amish from a county public health organization comprised the efforts to get the word out to the area's significant Amish population (wwnytv.com, March 27, "Getting information to the Amish during COVID-19 pandemic").

Some outreach took the more personal and direct form of meeting with Amish church leaders to distribute information and press the seriousness of the matter. In Daviess County, Missouri, health officials met with a local bishop in the Jamesport community and "provided paper resources to be passed out" in an effort to reach the area's thousand Amish residents (newspressnow.com, March 19, "Rural Northwest Missouri counties prepare for COVID-19"). Tapping Amish bishops as a means of quickly spreading important information was seen in numerous communities. For example, in Wayne County, Ohio, a local bishop and other leaders in the community publicized a testing clinic that had been organized at an Amish school following an outbreak in the community (cdc.gov, November 13, "COVID-19 outbreak in an Amish community-Ohio, May 2020"). Church leaders were not the only Amish figures used in educational efforts. In Lancaster County, "key contacts," including bishops, and even Amish EMTs and firefighters, were used "as additional trusted conduits for educational materials and rumor control" (Penn Medicine News, September 1, "How Amish communities are staying safer from the COVID-19 pandemic with help from good neighbors at Lancaster General Health").

Beyond the early-stage awareness efforts, several efforts focused on providing testing in Amish settlements. With the Amish living primarily in rural areas, and given the relatively limited mobility of a people reliant on horse-drawn transportation, several individuals and organizations sought to bring testing facilities to the Amish. This meant setting up mobile clinics and testing stations where they could be easily accessed by Amish without traveling far from home. In the central Pennsylvania Amish community in Mifflin County (the Kishacoquillas or "Big Valley" region), an effort led by Dr. Holmes Morton of the Central Pennsylvania Clinic brought a drivethrough testing center intended for both the local 4,000-strong Amish population and non-Amish 
residents (vice.com, April 6, "The Amish are getting a COVID-19 drive-through testing center for horse and buggies"). Not long after, two mobile clinics opened in the Elkhart-LaGrange and Nappanee settlements of northern Indiana (wsbt.com, April 23, "Mobile coronavirus testing sites open in Elkhart County to help Amish community"). Illinois's largest Amish settlement saw its own pop-up clinic appear in July. "There have been some people out there that want to get tested, but have not been able to go do it," explained a local health official (foxillinois.com, July 9, "Health officials bring pop-up testing site to Amish country").

\section{Theme \#2: How Did the Amish Initially Respond to the Virus?}

Next, we examine how the Amish responded to the virus - their attitudes and actions in the face of the pandemic as it unfolded in its first weeks, a time of elevated public concern. What attitudes, opinions, and beliefs did the Amish convey regarding the pandemic? What actions did they take, as far as adhering to restrictions on public individual and group activities, including the operation of schools, businesses, and churches?

Early coverage drew a contrast between English attitudes and those of the Amish, suggesting that the Amish were, on the whole, not as affected by fear of the virus. In an article for the York Daily Record, Amish people expressed confidence in traditional health and wellness practices, and a "trust in God." One Amish housewife stated, "We're probably not as scared," suggesting that not watching the news all day helped them remain calmer about the pandemic (York Daily Record, March 18/19, “We aren't as spooked': How the Amish are responding to the coronavirus"). An Amish bishop from the Elkhart-LaGrange County settlement of northern Indiana was more emphatic, advising others to "stay calm and don't let fear rule you. Fear comes from the devil, not God. God always takes care of his people" (Goshen News, March 22, "Amish bishops convene to discuss COVID-19"). The bishop stated that they will follow government mandates, encourage the sick to stay home, and limit gatherings such as weddings and funerals, but that "the church is the most important thing." He also affirmed that "if one of us dies from it, it's God's plan." This bishop's statements - noting that each church district will decide for itself-brought attention to the composition of Amish society as a collection of individual churches, many in groupings or affiliations simpatico with one another, but each essentially independent (Kraybill et al., 2013). In the case of the northern Indiana bishop's church, it had held its service as usual the previous Sunday, though took the precaution of not inviting people from other districts, normally a common Amish practice.

For those familiar with the Amish, attitudes such as those expressed above were not surprising. The underlying sentiment in these ideas is a bedrock Amish approach to life in this worldly "kingdom," summarized by the words "it's in God's hands." This sentiment is lived out to varying degrees across the Amish spectrum, and most markedly in the plainest Amish circles, some of whom, in the same spirit, reject slow-moving-vehicle safety triangles on their buggies and smoke alarms in their homes. That noted, the public statements in these two examples emerged from two of the largest and most progressive Amish communities. 
Members of Amish communities elsewhere acknowledged the seriousness of the burgeoning pandemic. An Amishman in the Daviess County, Indiana, settlement explained: "It impacts our way of life. We have never experienced anything like this, but we do recognize that this virus is real and it is serious. We are a lot like everyone else in that we are just learning about this as we go." (Kokomo Tribune, March 30, “Amish muster communities against COVID-19”). An Amish store owner in Maine acknowledged the fear in the general community, and reflected on his duty to others: "To me, it doesn't look like it will kill me. But I see myself as having responsibility to my customers, my community, and my family, of course." A further comment reflected a typical Amish grounding in Christian faith (although with an added confidence of salvation characteristic of a subset of churches, though not typical of the Amish as a whole): "I don't think we need to fear. We do trust in God and God will take care of us. And if we're ready to die, we know where we're going." (Bangor Daily News, April 2, "Even in the otherwise timeless Amish community, the pandemic has brought changes").

As the importance of adherence set in (at least in some places), reports emerged of adaptations undertaken by Amish. In Lancaster County, schools were the first Amish institution to close in mid-March, while Sunday church services and weddings continued to be held at that point (Lancaster Online, March 18, “Coronavirus threat closes Amish schools, but weddings, church go on"). A report in late May confirmed that "most, if not all" of the Lancaster County community's approximately 250 Amish and Old Order Mennonite schools had closed following the governor's order, with Amish scholars taking on remote assignments, and teachers providing worksheets, textbooks, and occasional in-person visits (Lancaster Online, May 30, "How did Amish schools handle the coronavirus pandemic? We asked 3 experts").

In New York's Chautauqua County, all Amish schools were reported to be closed in a March 19 report (wgrz.com, March 19, "Chautauqua County has no positive cases of coronavirus, but it is believed to be in the area"). At around the same time, Amish Kitchen columnist Lovina Eicher reported to her readers that all Michigan Amish schools had also been closed (Battle Creek Enquirer, March 19, "Amish Kitchen: Morning maple muffins from the new Lovina Eicher cookbook"). School closings appeared to depend in part on a given state's mandates and recommendations. In contrast to Lancaster County, the over 100 Amish schools in LaGrange County, Indiana, remained open - the Indiana governor had closed public schools but permitted private schools leeway - although, following a meeting among leaders in the community, most were "leaning toward the idea of closing the schools" (kpcnews.com, March 21, "Amish community prepares for COVID-19"). And in an interesting case, which we will return to later, the Geauga County Amish school board was described as being "ahead of the curve" in proactively inquiring if it should cancel the remainder of the school year (Geauga County Maple Leaf, April 21, "Charges Filed After Large Amish Party Shut Down").

The effect on Amish businesses and related events was reported relatively quickly. One prominent set of business events impacted by the virus were the "mud sales," annual auctions held to benefit volunteer fire departments in the Lancaster County community (the sales get their name 
from the typically muddy condition of fields during the spring thaw). Many of the volunteer firefighters are themselves Amish, and the sales, which have heavy Amish participation, are public events that typically draw significant attention and outsider participation.

By mid-March, three of the nearly two dozen scheduled events had been held. But the timing of lockdowns coincided with the beginning of the mud sale season; the bulk of the sales are held in the spring. Soon after the Gordonville event was held on March 14, "despite township officials urging the event to be canceled" as reported in Lancaster Online (March 12, "Gordonville mud sale to go on this weekend despite township officials encouraging cancellation"), cancellation and postponement notices began piling up for sales slated for the coming weeks and months. Most changes were publicized via the respective fire companies' websites and/or Facebook pages, though some appeared in traditional media sources as well (Southern Lancaster County Chronicle, March 17, "Coronavirus closings, information from Dr. Peterson"; Lancaster Online, March 6, "2020 mud sale calendar for Lancaster County and beyond, including cancellations and postponed dates").

Additionally, numerous tourist attractions and tourist-oriented businesses were shuttered early in the pandemic, including the Menno-Hof Amish/Mennonite Information Center in northern Indiana, the Amish \& Mennonite Heritage Center in Berlin, Ohio, and restaurants such as the Amish Door and Mrs. Yoder's Kitchen in the same community. Destinations in Lancaster County swiftly hung up "Closed" signs as well, including Shady Maple Smorgasbord and the Amish Experience tour company and theater. While most of these businesses are not Amish-owned, a number employ Amish workers. Amish in many places derive income either directly or indirectly from tourist dollars spent in their communities (Kraybill et al., 2013, pp. 391-394).

Different states had different rules regarding nonessential businesses (how they were defined, whether they were allowed to remain open, and in what capacity, if they were), and those rules affected the thousands of Amish-run enterprises in different ways depending on their locations. To take one example, many Amish businesses in a sizeable southern Indiana community were reported to "have gone ahead and closed," while others reportedly continued to operate after receiving confirmation from state authorities of their "essential" status (Kokomo Tribune, March 30, "Amish muster communities against COVID-19"). Bangor Daily News provided an up-close look at the way one Amish market store was complying in Maine. The aforementioned Maine store owner described adaptations he had made, including suspending the normally crowd-drawing "doughnut Wednesdays" and installing a Plexiglas barrier in the store (Bangor Daily News, April 2, "Even in the otherwise timeless Amish community, the pandemic has brought changes").

It was reported that several Amish communities had implemented restrictions on religious events fairly early in the course of the pandemic, though evidence indicates it was a more difficult decision to take for many than the choice to shutter schools. In Lancaster County, church leaders initially canceled services in March (pennlive.com, April 6, "The Amish present unique challenges amid coronavirus"). Amish in that community later took a decision to resume church services for Easter, but reversed it following the recommendation of representatives of an area hospital (Penn 
Medicine News, September 1, "How Amish communities are staying safer from the COVID-19 pandemic with help from good neighbors at Lancaster General Health"). In Ohio, the New York Times reported in early April, the state's Amish steering committee, a guiding body of leaders tasked with navigating public issues on behalf of the community (Kraybill et al., 2013, pp. 357360), advised that all churches respect the state's March 16 advisory limiting gatherings to 10 people. This came with a recommendation to stop holding church services and to either cancel or postpone other gatherings, including weddings, youth meetings, and family events. As Amish society is flat-structured, with each church district having autonomy, the committee's recommendations were, unsurprisingly, not followed by all. The Times found at least one example of Amish in the state holding a sizeable meeting, a post-funeral meal, after the recommendation was issued (New York Times, April 9/16, "In Ohio, the Amish take on the coronavirus").

Other reports brought news of Amish limiting or canceling religious events-for example, a community in Michigan that had initially held a wedding but later decided to "put a hold" on future weddings following pushback from neighbors (WTVB, April 2, "Concern over Amish wedding gathering in California Twp"), as well as in Geauga County, Ohio, though to a limited degree (ideastream.org, April 6, "Geauga County receiving reports of Amish residents not social distancing"). In late March, a member of the Amish steering committee in Daviess County, Indiana (a sizeable community in southern Indiana with 29 church districts), explained, "It is hard to think about not having church services. That is a decision that will belong to the bishops," but he also noted that a number of weddings had been postponed in the past week due to concerns over the virus (Kokomo Tribune, March 30, "Amish muster communities against COVID-19"). In the Unity, Maine, community, it was reported in early April that church services had "mostly been suspended" (Bangor Daily News, April 2, "Even in the otherwise timeless Amish community, the pandemic has brought changes").

Complicating factors were the importance of certain religious events in the Amish calendar including the biannual council and communion services, baptisms of new members, and weddings. Funerals, typically attended by hundreds of Amish, often coming from distant communities out of state, also presented challenges. The bishop from the large northern Indiana community said that people should limit weddings and funerals. In practice, that meant that only those closely related to the bride and groom, or to the deceased, should attend the events (Goshen News, March 22, "Amish bishops convene to discuss COVID-19").

\section{Theme \#3: Non-Adherence: Finding Fault and Assigning Blame}

While some stories emerging from the pandemic were neutral or even cast the Amish in a positive light, in other cases, the coverage was more negative. There were numerous reports of Amish failing to adhere, or allegedly failing to adhere, to local COVID-related restrictions in their communities. These typically revolved around Amish holding community gatherings in defiance of mandates. 
One early example, mentioned briefly above, was reported in southern Michigan, when Amish held a wedding in early April described as "planned before the COVID-19 outbreak." WTVB reported that this event "raised the ire and concern of other residents in the area." The Branch County sheriff contacted the bishop and received the explanation that, due to technological limitations, the families involved did not have an effective way of telling invitees not to come. The bishop was described as "very cooperative" when contacted the morning of the wedding, agreeing to limit the scope of the event and to halt future weddings until the pandemic had passed (WTVB, April 2, "Concern over Amish wedding gathering in California Twp").

\section{Geauga County, Ohio}

In reviewing the coverage, certain Amish communities appeared to garner more negative attention than others. The large Amish community of Geauga County, Ohio (covering parts of four northeast Ohio counties), led the pack in this category, receiving a cluster of negative coverage in multiple stories in April. The first appeared in early April when FOX8 reported on citizen complaints directed at the Amish community. Several non-Amish residents shared photos and alleged that Amish were continuing to gather for both "church and parties" (FOX8, April 6, "Geauga County health officials work with Amish to emphasize stay-at-home order").

One image featured in the accompanying video, the most potentially incriminating of the group, showed Amish playing volleyball on a front lawn, a common activity for youth at their Sunday gatherings. Two others depicted small groups of Amish walking together. A fourth photograph, inexplicably included in the report, revealed two Amish standing, at a six-foot distance from one another, outside of what appeared to be a bank's drive-through teller machine, presumably conducting bank business. Ohio's stay-at-home order in place at the time permitted exceptions, including allowances for getting "necessary supplies" and outdoor activity.

This report was followed by another two days later on an upcoming wedding in the community (wkbn.com, April 8, "Local health district addresses concerns that Amish community isn't social distancing"), and then a second report the next day of the Trumbull County authorities filing a notice of violation for Amish celebrants exceeding the 10-person limit at the wedding reception. Weddings themselves as religious events were exempt in Ohio from the restriction, but receptions were not (wkbn.com, April 9, "Health inspectors report social distancing violations at Amish wedding reception in Mesopotamia").

The next major bad behavior report on the Geauga community came on April 20. The Geauga County sheriff filed charges following a "large Amish party," as well as a summons for violating the state's stay-at-home order (FOX8, April 20, "We won't tolerate this,' Geauga Sheriff files charges after large Amish party"). It turned out that this was not the first such reported party in violation of state COVID mandates. A small notice of an earlier event (on April 5) appeared in a sheriff's report at around the same time, in the form of a noise complaint. A reported 75 to 90 Amish were in attendance at a party with loud music (Geauga County Maple Leaf, April 17, "Sheriff's Report"), with the homeowner described as saying that "he thought the stay-home order 
was only for the elderly." The sheriff characterized this response as the "standard answer" that they'd heard "several times" (Geauga County Maple Leaf, April 21, "Charges filed after large Amish party shut down").

Besides these stories, Geauga County had other lower-profile reports of law enforcement interventions at community gatherings. On April 8, a deputy brought a halt to a basketball game held inside a barn, with over 30 people in attendance. On March 29, deputies were dispatched to two meetings "involving religious ceremonies" where "they were advised of the complaints and asked to keep safe distances and follow safe practices," according to the sheriff (Geauga County Maple Leaf, April 21, "Charges filed after large Amish party shut down").

Two months later, the Geauga County health commissioner noted that the Amish population was the only demographic in the county where virus numbers were not declining. "Some in the Amish community apparently have a belief that the reports about the virus are overblown and perhaps not real," he said, citing an Amish bishop who told him of a church member who had a vision suggesting that if people failed to attend church, they would die of the virus. The Geauga County sheriff stated that his department received frequent complaints of Amish gatherings, but that the department would not be making arrests: "The Amish are a religion and they should be able to do what they want.... We don't have the manpower to enforce social distancing. We need to concentrate our efforts on real crime." At the same time, the sheriff also noted he had observed a positive change: increasing numbers of Amish were wearing masks in public (Geauga County Maple Leaf, June 11, “Geauga COVID-19 numbers show precautions are working”).

\section{KTVO in Iowa}

Another state that garnered negative coverage was Iowa, captured in two reports by television station KTVO — one regarding school closures, the second a livestock auction. In both cases, the actions of the Amish were at least arguably justifiable, though the station's coverage was decidedly negative.

The station first presented a story suggesting that the Amish of the Bloomfield (Davis County, Iowa) community were disobeying the governor's orders regarding school closures. Within the same story, the Davis County attorney reported that the local Amish had in fact been adhering to restrictions very diligently - holding two separate school sessions in order to limit the number of students to fewer than 10, in accordance with the existing rules, and cleaning classrooms in between.

To support their claims, KTVO showed footage of Amish children outside of a school, stating in a news segment that "some in these communities were observed on their way to school despite the governor's directive as late as Thursday." According to KTVO, this footage was recorded on Thursday, April 2, but erroneously described as April 5 in a caption on the article, the same day a new proclamation, an unclear order that could be interpreted as closing all schools, was announced at a 2:30 p.m. press conference (YouTube, April 2, "Iowa Gov. Kim Reynolds press conference| April 2, 2020"). In other words, the proclamation was made at the end of the school day on which 
KTVO captured its supposedly incriminating footage (KTVO, April 6, "Amish schools still meeting for class despite Governor's orders"). While the KTVO story attempted to present the Amish in a negative light, closer examination instead suggests it was more successful in raising questions about the news outlet's journalistic practices.

Several days later, KTVO covered the case of an Amish-run horse auction in the community at Seymour, Iowa. The Amish auction organizer decided to continue with the planned event on April 2, which was legally permitted at the time, as earlier reported by KTVO (KTVO, April 2, "Horse auction draws 400+ to Seymour amid COVID-19 outbreak"). The Amishman agreed to go along with safety precautions, including screening for all attendees and providing sanitizer. However, the community received negative coverage for the decision to hold the sale, prompting an area bishop to "sincerely apologize" on his people's behalf, even though it was technically within the bounds of the law governing livestock auctions (corydontimes.com, April 8, "Apologies from Amish community and bishops are sincere following horse sale"). Complicating the decision to proceed with the sale was the fact that the sale had already been set in motion, having been publicized in multiple states, and that the Amishman holding the event was under some personal pressure due to an impending move to Ohio.

\section{Other Negative Coverage}

In Pennsylvania, an Amish firm was the first business cited in the state for breaking the nonessential business restriction. The Lebanon County roofing company had reportedly been twice warned for holding close-proximity meetings without proper PPE (pennlive.com, April 24, "State police cite Amish contractor for violating coronavirus non-essential order").

Another strand of coverage centered on failure to adhere to mask requirements. A report early in the pandemic quoted a tour operator who claimed that Amish in Lancaster County were not wearing masks or practicing social distancing (triblive.com, March 28, "For Pennsylvania's Amish, the coronavirus and the call for social distancing are a challenge"). A month later, the mayor of a town in Chautauqua County, New York, declared that "the Amish are unable and unwilling to accept the laws of New York state" in an April board of trustees meeting. The mayor objected to Amish construction crews working: "They are not to be given a permit to work as a group any longer" (observertoday.com, April 20, "Mayor says Amish not distancing”). Reports of noncompliance by Amish continued into the summer. In Holmes County, Ashland Times-Gazette readers learned that multiple summer events drew thousands, "nearly all without masks." The majority of attendees were reported to be Amish (Times-Gazette, August 3, "Failure to mask up still a concern in Holmes, Ashland"). Notably, in an on-camera interview published in autumn but likely recorded in the summer, a Geauga County Amishman frankly admitted that many in his community were not wearing masks, particularly at community events (wkyc.com, November 16, "COVID-19 pandemic an "inflamed" and "largely ignored" topic for some in Geauga County $\underline{88 \text { Counties in } 88 \text { Days"). }}$ 
In other cases, in communities in Hazleton, Iowa, and Sinking Valley, Pennsylvania, Amish were mentioned as not complying in every situation - such as when in their own company, apart from English people_but generally complying otherwise (kwwl.com, June 19, "Amish community receptive to pandemic precautions"; Associated Press, May 30, "Amish stay abreast, make changes but maintain traditions"). And in one rather odd report, an Amishman in New York's Penn Station bathroom was questioned about his handwashing practices by a self-described "pesky Post reporter" (New York Post, March 14, "Coronavirus in NY: Penn Station commuters avoid washing their hands despite pandemic").

In addition to conventional reporting, some media outlets published letters from citizens expressing concerns over an alleged lack of mask-wearing by Amish. A letter writer pleading for both Amish and English to "unite to wear masks" asked the Amish: "My Amish neighbors, you wear head coverings atop of your heads. Why can't you wear coverings at the lower part of your heads when it could protect your neighbors?" (Wooster Daily Record, November 1, "Letter: Amish and English should unite to wear masks"). Another in the same area of Ohio cited Romans 13:1 in appealing to the Amish for greater respect of "governing authorities" (Wooster Daily Record, August 26, "Questions about masks for the Amish community”). Another letter, cosigned by 21 doctors and other medical professionals, while not naming the Amish, appealed to residents of Holmes County to practice social distancing and wear masks or face shields "out of love and concern for your vulnerable neighbor" (Bargain Hunter, July 10, "Local health providers ask for mask wearing, social distancing").

\section{Theme \#4: The Amish Respond: Helping Fulfill a Need}

One type of Amish response that received significant media coverage warrants its own section. The Amish have an ethos of mutual aid that undergirds their communities and is marshalled to assist afflicted community members in times of illness, tragedy, or disaster (Kraybill et al., 2013, pp. 187-188). A version of this ethos is often extended to the greater public in a spirit of Christian aid to those in need. Perhaps the most visible and oft-seen example is Amish aid to non-Amish communities following natural disasters such as hurricanes, floods, and other acts of God. Prominent examples include Amish cleanup and rebuilding projects along the Gulf Coast following Hurricanes Katrina and Harvey.

In a similar fashion, when a clear need materialized for face masks and other PPE such as gowns and mask covers, the Amish responded by tapping available internal resources - namely the skilled seamstresses found in nearly every Amish community. As Amish typically produce their own clothing, stitching and tailoring skills are learned at an early age. Amish responded by producing handmade face masks, made available either for donation or for sale.

The first media-reported example of this came in the nation's largest and most prominent settlement, Lancaster County. As detailed by Lancaster Online on March 25 ("Amid nationwide shortage of masks, Amish are sewing 13,000 to donate in Lancaster County"), it was a joint effort between a local non-Amish business, Amish sewers, and an Amish-owned shop, Bird-in-Hand 
Fabric. While not surgical grade, the masks were intended as backup supplies for hospitals and for churches and other institutions.

Signs of the Amish entrepreneurial spirit were evident in these efforts. While some maskmaking ventures were clearly charitable in nature, others had a business motivation driving the endeavor. One example of this is the effort led by a Sugarcreek, Ohio, manufacturer to produce PPE by harnessing the Holmes County Amish community's sewers (ideastream.org, March 27, "Amish Country businesses scaling production to make medical protective gear"). Several months later, it was reported that this effort had produced "several million" masks and gowns (wkyc.com; October 6, "88 Counties: How the Amish in Holmes County partnered with manufactures to combat COVID-19").

Further examples of mask-making and other PPE production were found in the ElkhartLaGrange settlement in northern Indiana (timesuniononline.com, April 28, "Amish community responds to needs of Goshen Health"), New Wilmington, Pennsylvania (Beaver County Times, May 1, "Put the pedal to the treadle: Amish women make masks, send all over the country"), and central Michigan (Mount Pleasant Morning Sun, April 30, "Mask-making mission knows no limits"). A month later, a report stated that Amish in Michigan were creating masks intended for use by members of the Navajo Nation, described by the outlet as having "the highest per-capita infection rate in the US" (copeprogram.org, May 29, "Amish communities in Michigan sew scientifically designed face masks for Navajo Nation").

\section{Theme \#5: COVID-19 Cases among the Amish}

How were the Amish directly affected by COVID-19, as far as contracting the disease? What reports identified cases and spread within Amish communities? Being a rural population, the Amish might be expected to be relatively isolated from the disease, which, at least initially, was most prominently associated with densely populated urban hot spots such as New York City and Milan, Italy.

However, the Amish are not at all isolated from interaction with non-Amish populations. They have direct contact with customers and tourists, visit health professionals and other businesses, and travel via "Amish taxis," vehicles driven by non-Amish outsiders, for example (Kraybill et al., 2013). Additionally, with their activity in business (including residential construction and retail market stands) bringing them frequently to major population centers, the Amish in the twenty-first century are hardly physically confined to a strictly rural existence in their home areas, as may have been more the case in past eras.

Furthermore, Amish families are typically of very large size -8 to 12 members in one household is not uncommon - and they frequently engage in communal events that bring them into contact with other members of the community (Kraybill et al., 2013, pp. 156-158). This reality, coupled with reports of Amish not wearing masks or following social distancing practices among themselves, likely contributed to concern among non-Amish over Amish communities potentially harboring and propagating the disease. 
Reported COVID cases were infrequently publicly confirmed as "Amish," although in some instances they were. The first reported death of an Amish person associated with COVID-19 appeared in the Fort Wayne Journal Gazette on April 12 ("1 Amish death in LaGrange; education efforts in motion"). In Macon County, Missouri, the health department confirmed a positive case in the Amish community in May (KTVO, May 29, "Macon County Health Department provides update to Amish COVID-19 case"). Outbreaks in Amish communities were identified, or suspected, in other places. A June outbreak in Ashland County, Ohio, was pegged to an Amish wedding by the Ashland County health department (cleveland19.com, June 18, "COVID-19 outbreak among Ashland County's Amish community originated from wedding, health department says").

Other reports cast suspicion upon the Amish community based on accounts of health officials who had dealings with the Amish. For example, in June, a Philadelphia Inquirer piece raised concerns about cases among the Lancaster Amish population, citing a public health official who stated that Amish and members of other Plain churches were declining to be tested even when presenting with COVID-19-like symptoms (inquirer.com, June 27, "More COVID cases in Lancaster County raise concerns as officials seek to determine virus' spread among Amish"). A second report in September raised questions about the frequency of testing among the Amish, with a hospital executive explaining that it was difficult to determine testing among the Amish due to the absence of religion-based data, while also claiming, "We know they are not going for tests" (pennlive.com, September 9/14, "How Lancaster County has endured the coronavirus pandemic"). At the same time, this individual also stated that the hospital had not had more hospitalizations of Amish than of members of other groups. In Indiana, the LaGrange County health officer also expressed the belief that many were ill with COVID-19, but refused to be tested, "especially within the Amish community" (kpcnews.com June 13, "Rising COVID-19 infections frustrates LaGrange County health officer"). A tendency to treat ailments via nonconventional means-home remedies and alternative treatments - and lower usage of traditional sources of health care such as family doctors and hospitals (Hurst \& McConnell, pp. 220-258) likely also contributed to the anecdotal reports of Amish testing for COVID at lower rates than the general public.

An August report shined the spotlight on cases in the Nappanee, Indiana, settlement (indystar.com, August 21, "Some Amish practices could contribute to spread of COVID-19 among the community"). A family medicine doctor reported that each of the Amish households in the area she serves (her "mile") had seen cases of COVID-19, an estimated 60 individuals. Among the most robust information published on COVID among the Amish was a report on the CDC website concerning a May outbreak among Amish in Wayne County, Ohio. This information appeared in a November edition of the Morbidity and Mortality Weekly Report, and detailed " 30 persons with laboratory-confirmed COVID-19" (cdc.gov, November 13, "COVID-19 outbreak in an Amish community - Ohio, May 2020"). 
Finally, in a tragic case, an Iowa woman shared that she believed her husband contracted the virus after transporting an Amish family, though she did not place blame on the Amish (kcrg.com, September 8, "Southern Iowa woman spreads message after losing her husband to COVID-19").

\section{Theme \#6: Coverage after "Reopen" and Return to "Normal"}

What coverage of the Amish emerged following the staggered period of reopening when state and regional strictures were eased over spring and summer, and businesses, churches, and gatherings were permitted to once again operate at a full or diminished level?

First, we learned that those Amish who had placed restrictions on church services resumed or planned to resume meetings in different ways. In preparation for a return after suspending services in March, leaders in the Lancaster Amish community provided five recommendations for congregations, including canceling the after-service fellowship lunch, banning handshakes, and forbidding the common practice of visiting among congregations (Mennonite World Review, April 27, "Pandemic disrupts Plain life"). Other adaptations were reported. In Iowa, writer Mary Swander, the state's early alerter mentioned in Theme \#1, shared that Amish in her community had "circled their buggies in empty pastures, families staying put inside their carriages. Their bishop preached from the middle of the circle" (Vox Populi, September 24, "Mary Swander: Covid-19 among the Amish"). In Michigan, Amish columnist Lovina Eicher wrote of her church's first meeting since the lockdown in early May (Mansfield News Journal, May 13, “Lovina's Amish Kitchen: Rhubarb custard pie mark the start of spring”). Similar to the Lancaster plan, Eicher's church skipped the post-service fellowship meal: "It didn't feel right not to sit and visit and have lunch with our church fellowship, but we are thankful that we could at least gather together to hear God's word."

Eicher further provided an update in the same column on how her family was faring on the economic and business front, delivering the mixed news of her son's return to work at a horse trailer factory after being furloughed since late March, while her husband, she noted, was still laid off. Meanwhile, an optimistic article had appeared in late April concerning an important Amish industry - furniture production. Trade publication Furniture Today reported that the Amish furniture industry was ready to "hit the restart at a run" and featured extensive input from both Amish and non-Amish sources in the industry (Furniture Today, April 27, "Amish producers say they'll hit the restart at a run"). The Amish CEO of an Ohio furniture wholesaler was hopeful but cautious about his state's planned May easing of restrictions: "Obviously the stores will have to open up to keep us going. And obviously, we will be a little careful to whom we ship; we have to get paid for it."

Shedding light on how some Amish businesses may have adapted to the COVID disruption, two articles appeared in September detailing how one Amish business - a central Pennsylvania cheesemaker named Goot Essa ("good food" or "good eating" in Pennsylvania Dutch)—had adapted to the pandemic by shifting to an online business model, tapping the help of a non-Amish third party (Centre Daily Times, September 6, "Centre County Amish-run business responds to 
COVID-19 with move into online retail"; Philadelphia Inquirer, September 30, "Amish cheesemaker Goot Essa preserves tradition with cave-aged specialties and online sales"). Not all Amish had this option available to them, but it suggested that Amish entrepreneurs in churches progressive enough to allow it might adapt within similar bounds to survive a disrupted economy.

In several instances, Amish were reported to have returned the stimulus checks dispersed across the nation as part of an economic relief program, in keeping with traditional Amish views on government aid. These actions were not the main point of any identified article, but were mentioned in several articles covering communities in Maine, Ohio, and Iowa (News Center Maine, May 26, "The coronavirus pandemic's impact on the Amish community"; Cincinnati Enquirer, October 28/31, “Going Home: 'I wish they'd vote. They love Trump.' A day with the Amish in Southeast Ohio"; Vox Populi, September 24, "Mary Swander: Covid-19 among the Amish").

\section{COVID Case Increases after "Reopen"}

Finally, after entering the period of loosening restrictions, there were several reports on COVID incidence upticks in Amish areas. These reports also garnered some response from non-Amish community members in both the medical and business fields - with criticism directed in different directions.

Several stories focused on the response of Holmes County, Ohio, officials to reports tying increased COVID cases to the area's reopening to tourism. A report in mid-June, over a month into the state's phased reactivation plan, pointed to a case rate in Holmes County "rival[ing] the state's peak at slightly over 50 new weekly cases per 100,000 people" (Wooster Daily Record, June 13, "Holmes County seeing coronavirus spike"). The Holmes County health commissioner was quoted, saying that a "late wave" was expected in rural areas, and that the pandemic was under control in the county, with low deaths and hospitalizations. The article also reported that health district data showed that Amish had been affected by the virus to about the same degree as other communities.

In contrast, an official in the comparable LaGrange County, Indiana, community discussed the pandemic in much different terms. Reacting to the area's own spike in COVID cases, the LaGrange County health officer appeared to cast blame directly upon the Amish segment of the population: "I'm concerned that there are more cases out there than are being tested. I think a lot of folks are already sick and won't get tested, especially within the Amish community" (kpcnews.com, June 13, "Rising COVID-19 infections frustrates LaGrange County health officer"). He faulted "health illiteracy" among residents of the area, expressing frustration that local residents were failing to comply with contact tracing efforts. The official further described Amish lifestyle practices, such as shared phones and delays in responding to phone calls, as "a cultural problem" exacerbating the pandemic.

These two articles, appearing on the same day amid comparable circumstances, provided a stark contrast in public messaging by key health officials towards the local Amish communities. 
The bulk of the Indiana official's reported comments framed the uptick as an "Amish problem," while his counterpart in Ohio took a broader view, making no mention of the Amish in his reported statements.

In Holmes County, a second report two weeks later pointed blame more directly at the area's opening to tourism. In a piece for the Wooster Daily Record, the writer suggested that Holmes County officials were contradicting data showing an uptick in cases: "The numbers say one thing. Holmes County officials are saying another." The implication was that county officials were somehow contradicting a truth confirmed in the numbers.

A thorough reading of the article revealed that the officials were in fact suggesting a possible explanation that likely ran counter to the writer's view, and to the popular narrative. Rather than agree with the assumed explanation that the uptick in cases was due strictly or primarily to increased tourism, the health commissioner offered the possible explanations of increased interaction among people and increased testing (Wooster Daily Record, July 1, "Holmes County officials: Tourism not causing coronavirus spike"). As data is simply data and does not come with a built-in explanation, it must be interpreted. The county's chief health official offered his own interpretation.

Several months later, the situation appeared to have escalated. The Daily Record reported that Holmes County officials had formed a "COVID-19 defense team" comprising over two dozen local officials. The team was ostensibly formed in response to a request by the governor for leaders and officials to make every effort "to keep the community open and be smart about it through the latest surge of coronavirus." In this report, two officials pushed back, criticizing those who focused on the Amish when assigning blame for the virus's spread. The chamber of commerce director was quoted as saying, "Some of the larger cities around us have sensationalized the messaging, focusing in on the Amish community." The Holmes County health commissioner made another appearance, stating that COVID-19 is not an "Amish-English" issue, and that he was "really disappointed to see people play that stigma of our community" (Wooster Daily Record, November 9, "Holmes County officials form COVID-19 defense team").

\section{Theme \#7: Collateral Damage}

There were a number of secondary effects beyond the obvious debilitating impacts on health, social interaction, and business activity that nearly all populations affected by COVID-19 sufferedoften unforeseen disruptions to life. The Amish were not immune. In wrapping up this media survey, the following are three examples of "collateral damage" suffered by the Amish as a result of the pandemic.

As a famously "offline" people, the Amish rely on sources of information and entertainment that have fallen out of favor with many of their non-Amish counterparts. One example of this is the library. Some Amish communities are served by local libraries' bookmobiles. For example, the Wayne County, Ohio, public library system operates a colorfully painted bus to deliver reading 
material to children in the county. These mobile libraries are particularly popular with the Amish population.

In early August came the news that the LaGrange County, Indiana, bookmobile, a regular visitor to over 60 local Amish schools, would be shutting down for the autumn season due to COVID-19. The closed interior space and frequent stops in different schools were judged a potential hazard. As a substitute, library staff planned a plastic tub system, with monthly drop-offs and collections, and deep cleaning of books, if necessary, before placing them back in circulation. The county library system remained open but under limited hours (kpcnews.com, August 1, "Library to keep bookmobile off the road for now").

Another area where Amish were indirectly impacted came in the form of COVID-related changes to the national passenger train system. Amtrak announced in late June a reduction in service of its California Zephyr line, reducing travel to a Colorado town called Glenwood Springs to three days per week. The resort town happens to be a popular destination for Amish people, who are relatively frequent Amtrak users. A local tour business owner explained, "We have a lot of Amish visitors that come to us by train from Indiana, Illinois and Pennsylvania," accounting for an estimated 95\% of the business's Amish customers. The town's tourism director added, "Our Amish visitors make up quite a significant number of our visitors in the summer and early fall" (postindependent.com, June 30, "Amtrak to reduce daily service to Glenwood this fall, potentially pick it back up next summer").

Finally, a potentially more serious secondary effect than reduced access to books and train service came in the early release from imprisonment of Sam Mullet, bishop of a rogue Amish church responsible for a series of beard- and haircutting attacks against Amish in 2011. Mullet, described as "an evil, dangerous person...a cult leader" by one Amish letter writer, had generated such a degree of fear in the Amish community that some had requested he be given life imprisonment at the time of his sentencing (Amish America, February 5, 2013, "Some Amish want life sentence for Sam Mullet").

During the pandemic, authorities in many states had taken steps to reduce prison populations, including temporary release, commutation of sentences, and parole, due to concerns over outbreaks in closely confined and densely populated prisons (Prison Policy Initiative, accessed November 6, "Responses to the COVID-19 pandemic"). Word came fairly early in the pandemic that Mullet, serving a 10-year, 9-month sentence for his role in the attacks, was requesting release, justified in part by his age and his heart condition (cleveland.com, March 18, “Amish bishop Sam Mullet, who orchestrated beard-cutting attacks in Ohio, wants out of halfway house because of coronavirus"). A report came soon after that Mullet had been granted his request and was to serve out the remaining months of his term under house arrest, under the Elderly Offender Home Confinement pilot program (Associated Press, March 23, "Leader of Amish beard-cutting attacks will get to go home"). 


\section{Analysis and Further Questions}

On reviewing this survey of media coverage, several points and questions present themselves, on both the nature of the coverage and the various Amish responses to the pandemic. What follows are concluding reflections on topics under these six headings: (1) Amish faith vs. English caution, (2) shutting down: schools vs. church services, (3) a minority group it's okay to point a finger at, (4) negative coverage: Anti-Amish bias? (5) Holmes County Amish apologism? and (6) bringing out their best.

\section{Amish Faith vs. English Caution}

A common theme that emerged from comments made by the Amish was that they were less concerned about the virus than they ought to be - at least when viewed through a certain nonAmish lens. Lack of adherence to public health measures or absence of great concern over the virus may have been driven by a lack of information on the dangers the pandemic posed, at least initially. But some common threads became evident when Amish spoke of how they were responding to the situation, which could be summarized thus: "We're not as afraid, we're going to trust in God's plan."

How much did this attitude influence adherence to various requirements and "best practices" in their communities, including gathering restrictions and mask-wearing? Outsiders often saw Amish behavior in these areas as a puzzling lack of concern for their own, or worse, for their nonAmish neighbors. One woman working in the medical profession wrote, "I have been hurt and disappointed by the refusal of many of my Amish patients to wear a face covering. I've been told that I'm 'ridiculous' and 'dumb' to request masking. I wear one to protect my patients and I would truly like to understand why they refuse to offer me and my other patients the same courtesy" (reader comment, Amish America, August 22, "Ohio COVID-19 outbreak traced to Amish wedding").

The COVID crisis brought Amish practices and attitudes toward health care into sharp relief for those non-Amish who encountered unmasked Amish people — but also for a wider audience who read reports of Amish expressing sentiments such as "We're not as spooked [by the virus]." The stark contrast between the media-amplified "Amish" attitude and approach and that of the religiously mask-wearing, hand-sanitizing, social-distancing segment of the English population was hard to miss.

\section{Shutting Down: Schools vs. Church Services}

Though Amish took steps to close both schools and churches, looking at the reporting as a whole, it appears that Amish schools were among the first Amish institutions to shut down; in most cases, the Amish ceased operating their schools earlier and more readily than their religious services.

For example, in Lancaster County, it was reported in May that "most, if not all" Plain-sect schools had closed, as was the case in reports from communities in Michigan, New York, and other 
states. In Geauga County, school board leaders in the nearly 19,000-strong Amish settlement even took the initiative to ask health authorities if they should close for the remainder of the year.

By their reported actions and public comments, there appeared to be more reluctance about halting religious services - for example, from the northern Indiana bishop who said the decision on Sunday services remained with individual churches and that weddings and funerals would continue on a limited basis, or the Amishman in southern Indiana who found the idea of stopping church difficult to imagine. We also saw evidence of church events continuing, particularly weddings and funerals - in Holmes County, in southern Michigan, and in the same Geauga County that appeared ready and willing to shut down their dozens of community schoolhouses for the term.

This makes sense when considering Amish identity as a devout Christian people, for whom the church body and its regular gathering holds great importance-and certainly a higher importance than schooling intended to help their children acquire a degree of practical knowledge in order to function in a secular world (Johnson-Weiner, 2007). It turned out to be easier to close Amish-run schoolhouses than it was to halt the three-hour church meeting and fellowship meal, religious events that encompass the full church community. One might even suspect that some Amish families - and certainly more than a handful of Amish children - would not have minded if shuttered schoolhouses meant additional hands to put to use at home or around the farm.

A comparatively lower incidence of church closure may also stem from the nature of Amish society as a collection of autonomous churches. Each Amish congregation has its own leadership, and it may or may not be "in fellowship" with neighboring churches. While Amish churches may act similarly, particularly (though not always) when they are of the same affiliation (Kraybill et al., 2013, pp. 137-154), the northern Indiana bishop's comments that "the church is the most important thing" and that each individual church in his community of nearly 200 districts would decide independently reflect the reality of the individual autonomous status of each Amish church district.

\section{A Minority Group It's Okay to Point a Finger at}

It is not uncommon for the Amish as a minority group to be spoken of in ways that numerous other religious, ethnic, or cultural minorities likely would not be. This was evident prior to the COVID epidemic, and we saw examples of it in the COVID-related coverage reviewed above (see the concerned Holmes County letter writers, the comments of the health officer from LaGrange County, and those of the New York town mayor). It is not unusual for observers to freely discuss "the Amish" and publicly ascribe positive or negative attributes to them as a group, in ways that they would likely be less comfortable doing when discussing other ethnic, religious, or cultural groups. While the Amish are not unique in this experience (see recent examples such as overgeneralizing of "the Hispanic vote," or coverage of COVID responses in New York City Jewish communities), they recurringly find themselves recipients of such broad-brush treatment. 
Why might this be the case? There are several possible reasons. One is the status of the Amish as a minority but one with ethnic majority characteristics, namely being predominantly a white European Christian group. In other words, the Amish have the same ethnic makeup and general religious background as the majority of the U.S. population.

Another may be that the Amish are at least to some degree understood by the public to be a nonresistant people, a group that does not file lawsuits and defamation claims. Thus, there might exist a greater feeling of freedom and less sensitivity when speaking of them in-sometimes derogatory_-blanket terms and descriptions.

Relatedly, commenters may also feel insulated because they know that the Amish are not an "online" population — and are unlikely to retaliate in that medium — or perhaps, they might assume, are unlikely to even become aware of comments made in conventional media forums.

Another reason is that while the Amish community is at its core a religious community, this may not be well understood by the public. Thus, the Amish might not be seen as a religious group in the same way that Muslims or Jews are. It is quite possible that those with little understanding of Amish motives see them as more of a lifestyle group - people who simply choose to live in an odd way for nonreligious reasons, like 1960s hippies, commune members, or adherents of other countercultures. With the more sensitive religious element removed or poorly understood, the stigma against grouping them together and painting them with a broad brush may diminish or disappear.

Finally, the well-ingrained perception of the Amish as a peculiar group of people residing physically and figuratively outside of modern society may simply cause observers to think and speak of them in terms reflecting this status - in other words, with less consideration for them as outsiders than for those minority groups viewed as integrated with, and protected by, the rest of English society.

\section{Negative Coverage: Anti-Amish Bias?}

Negative coverage can be driven in different ways. Some negative coverage may be generated by the biases or lens of the person writing the story. In other cases, it may reflect objectively bad behavior. As regards bias, it is worth noting the observations of Umble and Weaver-Zercher of a long history of media affixing broad meaning to the collective Amish-furthering narratives often starkly negative or positive in comparison to the dominant society. These have ranged from depictions of the group as progress-resistant "dumb Dutch" in the 1910s and 20s to widely positive accounts of their capacity for forgiveness and "extraordinary grace" following the Nickel Mines school shootings of 2006 (Umble \& Weaver-Zercher, 2008, pp. 12-14). Are the Amish as pandemic protocol miscreants the latest example of this phenomenon?

Relevant questions here include: (a) Were the Amish singled out for unjust criticism in some cases? and (b) Did media outlets demonstrate bias towards the Amish in their reporting?

In my opinion, the most egregious example of (a) would be the Bloomfield, Iowa, school story as reported by KTVO, complete with questionable "gotcha" footage of Amish children outside a 
school. Considering the counter report from a source in the same story of local Amish diligently following COVID sanitation guidelines, as well as the timing of the governor's new (and confusingly presented) order, this story raised questions about the intentions of the reporter, and at the least, about the quality of the reporting.

It may be the case that negative predispositions toward the Amish-either on the part of journalists or community officials - led to unfair coverage in other examples. For one, the Wooster Daily Record reporting around the Holmes County uptick, pinned unquestioningly on Amish tourism, could be seen through this lens. The comments of the LaGrange County health officer certainly seem to reveal a largely single-minded focus on the "cultural problem" of Amish behavior as the main driver of LaGrange County's COVID case increase - especially when contrasted with what appeared by comparison to be more measured and cautious comments from his Holmes County counterpart.

Negative coverage can also come about when noncompliance is brought to public attention by neighbors. Of the Amish communities in question, Geauga County generated the most reports of "bad behavior," some of it conveyed by non-Amish residents in the community. The question remains as to whether the Geauga Amish in fact "behaved more badly" with regards to COVID adherence or if, perhaps, Amish-English relations are of lower quality in this community compared to comparable settlements, such as Holmes County, where public officials vigorously defended the Amish against blame casting, or in the Elkhart-LaGrange settlement.

Another example of questionable reporting would be the report by FOX8 of Geauga County Amish breaking the state's stay-at-home order, backed in part by the use of some questionable or arguably irrelevant images submitted by local residents, supposedly showing this to be the case.

On the other hand, numerous other reports appeared to detail legitimate cases of rule breaking and noncompliance, including the account of the Geauga wedding reception exceeding the 10person limit, as well as multiple Amish-attended parties that law enforcement responded to in the community. To take another example in the state, in Holmes County, a report that masks were hardly seen at several high-attendance, majority-Amish summer events also appears to be an example of largely objective reporting.

Considering the above examples as part of the whole of the collected coverage, it would appear there were some, though relatively few, cases of blatantly negative coverage that could be suspected of being driven by biases on the part of reporters or other observers and contributors.

\section{Holmes County Amish Apologism?}

Officials in Holmes County appeared to be among the most sympathetic toward the Amish, or at least, they were less likely than officials in many other places to point a finger at the Amish for their behavior or to affix blame on them for increases in COVID cases.

On the one hand, there were numerous examples of the Amish being tagged for their failure to adhere to COVID strictures: the statement by the town mayor in Chautauqua County, New York, that Amish were unwilling to accept state laws; the harsh criticisms of the health officer from 
LaGrange County; the suggestions of multiple officials in Lancaster County (albeit not government officials, as the county lacks a formal health department) that the local Amish were testing at too-low rates; and even the more measured critiques of the Geauga County health commissioner.

In contrast, most input from local officials appearing in coverage of the COVID situation in Holmes County lacked any direct assignment of blame to the Amish community. The health commissioner there, in reported statements, tended to suggest causes of case increases that were more general - for example, more interaction between people in the area and increased testingrather than assign the blame to the area's large Amish community. He also suggested a "late wave" was to be expected in rural areas. In other words, this official tended to generalize when discussing potential causes of higher test numbers rather than assign causation, as others tended to do, to the Amish population.

The Holmes County health commissioner also abstained from blaming the Amish directly in later reporting on events heavily attended by Amish not wearing masks. Instead, he pointed to being unaware of the events until after they had occurred and to having limited resources for enforcement. In the same reporting, he urged mask-wearing, social distancing, and other widely promoted pandemic-reduction measures. In this instance, his only reported comment regarding the Amish was that he had worked with the community in the past, and that they had "been cooperative in accepting educational information" (Times-Gazette, August 3, "Failure to mask up still a concern in Holmes, Ashland").

Finally, it was reported in November that community leaders in Holmes County had formed a "COVID-19 defense team." It was in this account that the health commissioner, along with another leader, mentioned the Amish directly, in this case to address perceived stigmatization. The health commissioner expressed disappointment at people casting COVID as an "Amish-English" issue, while the director of the chamber of commerce pointed at outsiders "sensationaliz[ing]" and "focusing in on the Amish community."

In contrast, though some officials in Holmes County may have been reluctant to take the Amish to task, a number of area residents were willing to offer at least mild rebukes in the form of letters to local media outlets calling upon the Amish to wear masks. A third letter from health professionals asking the public to adhere to mask-wearing and social distancing refrained from mentioning the Amish directly.

On the one hand, it could be that the individuals in LaGrange County, Chautauqua County, Lancaster County, and elsewhere were all biased to some degree against the Amish, unfairly pointing a finger. It may also be that the health commissioner of Holmes County demonstrated a bias in the other direction if, as going by his reported comments, he abstained from publicly attributing a potential Amish element to the local increase in cases.

Beyond that possibility, might other factors be at play? Holmes County is heavily Amish, one of the most Amish counties in the nation. The community itself is close-knit, and the Amish generally enjoy good relations with the English. The local economy is dependent on tourism, and 
there are many small businesses among the Amish. It is possible that the health commissioner, in this role since 2015, has developed a closer relationship with local Amish than other individuals mentioned with their respective communities. Perhaps, by disposition or by virtue of having close relationships with key figures in the Amish community, the Holmes County health commissioner is simply less apt to publicly cast blame, while doing more of his work and influencing behind the scenes.

Leaving speculation aside, what's true is that there was a noticeable difference in the public approach of Holmes County's chief health official regarding messaging around the Amish and COVID-19, and the public approach of officials in other Amish-heavy parts of the country.

\section{Bringing Out Their Best}

The most positive strain of coverage the Amish received was about their production of masks and other PPE. This type of coverage fits the Amish, and society's expectations of them, in several ways. For one, the coverage demonstrates that they are a Christian group selflessly (though maybe not entirely) contributing to help their neighbors and fellow humans both locally and in distant places in a difficult time. Two, the type of aid suited popular perceptions of the Amish — creating homemade textile products using sewing machines, in some cases, old-fashioned treadle machines. And three, the efforts had a grassroots, localized, small-scale feel-women hard at work in their homes, each individual one of many working for a greater cause.

These stories found a ready audience in a public craving positive stories. "This is a lesson all Americans should learn and take into their own lives. Long Live the Amish," wrote one website commenter (reader comment, Amish America, March 26, "Amish sewing 13,000 masks for donation"). And it probably did not matter much that not all these efforts were strictly charitable, although a number appeared to be.

The Amish, by nature of their culture and education system, do not produce scientists, researchers, or doctors. If they were to play an important positive role in the efforts against COVID, it would not be by leading clinical trials or treating patients on the front lines. Activating their communities' sewing capacity to create millions of masks and other PPE items was the positive role the Amish were well-positioned to assume.

\section{Conclusion}

The Amish as a group receive outsized attention in normal times. Beyond the superficial differences of a distinct low-tech, plain-dressing, German-speaking group, the deeper aspects such as cultural mores, religious customs, social structure, and general worldview, when revealed, can stand in stark contrast to those of their non-Amish neighbors.

In normal times, these differences are often highlighted in recurring stories on controversial niche topics - such as the reluctance of some Amish to use safety lighting and emblems on their buggies or their refusal to vaccinate against certain diseases. These types of stories tend to emerge from the more conservative corners of Amish society, since that is where the distance between 
"Amish ways" and "English ways" is greatest, and thus the potential for contrast and conflict greatest. These stories can also reinforce the concept of diversity among the Amish, bringing intraAmish differences to the forefront. Observers look at the "strange Amish" in one community and wonder why they cannot behave more like the "normal Amish" in their neighborhood, whose buggies are well-lit at night.

Things have been a bit different during the COVID-19 pandemic. Circumstances surrounding the pandemic provided an environment for media coverage that accentuated Amish differences in a more encompassing fashion. And since the variable of COVID-19 was more or less the same across all Amish communities (notwithstanding some local variation in government restrictions), it served to highlight some of the more universal and unifying traits found across churches and affiliations, from conservative to progressive.

In other words, some stark differences between the actions and views of Amish and the "correct" COVID behavior and views promoted by many of the loudest voices in the broader society did not solely appear among the most "extreme" Amish, as might be the case with the bulk of this type of media story in a COVID-free era. They emerged in the progressive communities as well. After all, it was in the Holmes County settlement where news appeared of thousands of Amish going maskless at numerous events. It was in a similarly progressive Pennsylvania community that the state's first nonessential-business violation was registered, after the errant firm first collected two warnings.

To take one example, Amish attitudes to death and risk - no doubt startling to some of the more safety-obsessed non-Amish - were brought to the forefront in comments and implied in reported behavior regarding masks and social distancing in various communities. In normal times, we may have read the odd story of some very plain Amish in a corner of New York State curiously rejecting smoke alarms in their home, with one condemning them as the "devil on the wall" (BBC, May 19, 2012, "New York Amish in court over smoke alarms"). But during COVID-19, we learned - or were reminded - that it was not just the most traditional Amish who seem to tolerate a much higher level of risk than does a good portion - perhaps the majority — of the public. As the bishop in the generally very progressive northern Indiana community said, "If one of us dies from it, it's God's plan." There was also the Maine business owner who stated, "I don't think we need to fear. We do trust in God and God will take care of us." Or consider the "Amish spokesman" for the Geauga County settlement who admitted that many in his area were not wearing masks, especially at community events (which, if going by police reports, apparently continued unabated, at least in some parts of that settlement). Reports of mask offenses were not isolated to the plainest corners of Amish society, nor were comments revealing attitudes to risk and death demonstrating a lack of fear. These statements and corresponding behaviors were buttressed by a strong underlying religious faith shared by Amish of all stripes.

Though in several ways a significant number of Amish - the more progressive, businessminded groups in particular - have become more like the English over the past several decades, these and other examples are a stark reminder that, overall, Amish attitudes remain in significant 
ways strikingly different from those of the millions of diligently masked, disinfected, and selfisolated souls in the general public.

Likewise, it was not just the odd outlier Amish groups who placed high priority on the tightknit church community. In a country of religious phenomena like technology-enhanced megachurches and practices such as "church-hopping," the shared Amish emphasis on the importance of holding in-person church services and their dedication to the autonomy of their small, close-knit congregations stand out. Though some Amish did suspend church services, they did so with reluctance. In some places, weddings and other religious events were held in the face of public disapproval. Accounts such as these accentuate features of the Amish as a faith group with imperatives to live autonomously and reduce outside interference with their beliefs and practices.

When considering two cultures (Amish and non-Amish) exhibiting such stark differences in both lifestyle and worldview, some adaptation and accommodation is necessary to, at the least, coexist, if not thrive living side-by-side. Moving forward into a possible year two of the COVID19 pandemic, respecting Amish autonomy, as it were, means that local governments would do well to consider and adopt solutions taking into account and respecting Amish differences, to the degree that it is feasible. Likewise, for the Amish to remain good neighbors, an adherence to reasonable restrictions designed to preserve public health that do not egregiously interfere with core religious principles and practices will go a long way towards building and maintaining cross-cultural community ties.

\section{References}

Johnson-Weiner, K. M. (2007). Train up a child: Old Order Amish and Mennonite schools. Johns Hopkins University Press.

Kraybill, D. B., Johnson-Weiner, K. M., \& Nolt, S. M. (2013). The Amish. Johns Hopkins University Press.

Hurst, C. E., \& McConnell, D. L. (2010). An Amish paradox: Diversity and change in the world's largest Amish community. Johns Hopkins University Press.

Umble, D. Z., \& Weaver-Zercher, D. L. (Eds.). (2008). The Amish and the media. Johns Hopkins University Press. 